\title{
Gerakan Budidaya Tanaman Obat Keluarga sebagai Kepedulian Masyarakat Menuju Desa Sehat di Desa Semen Kabupaten Kediri
}

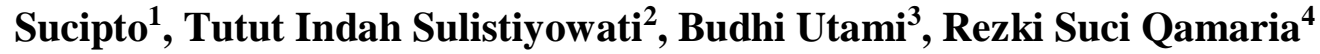 \\ ${ }^{1,2,3}$ Universitas Nusantara PGRI Kediri, ${ }^{4}$ Institut Agama Islam Negeri Kediri \\ email : sucipto@unpkediri.ac.id ${ }^{1}$, tututindah@unpkdr.ac.id ${ }^{2}$,utamibudhi@unpkdr.ac.id ${ }^{3}$, \\ rezkisuciqamaria@iaiakediri.ac.id ${ }^{4}$
}

\begin{abstract}
Traditional medicine is still excellent for the people of Indonesia, especially those in the village of Semen, North Semen District, Kediri Regency. However, people have still been buying traditional medicines in the market. Even though the village has the potential to cultivate family medicinal plants such as ginger, lemongrass, turmeric, and curcuma. Residential land in the village of Semen reaches about a quarter of the total land area $(48.81 \mathrm{Ha})$ which gives the opportunity for the movement of family medicinal plants to be carried out in the yard or yard of the residents' houses. Therefore, team took the initiative to create a family medicinal plants cultivation movement program with the aim of providing knowledge, understanding, and skills to the village community related to the use of medicinal plants, how to cultivate medicinal plants, and how to process medicinal plants for consumption. The activity carried out is to invite local residents to jointly make land in front of their homes and plant several types of medicinal plants. Furthermore, local residents were given socialization related to the benefits and hands-on practice in processing these medicinal plants. As a result, the movement to plant family medicine is able to change the awareness, skills and behavior of healthy lifestyles of people in the village of Semen.
\end{abstract}

Keywords: cultivation movement, family medicine plant, healthy village

\begin{abstract}
Abstrak
Pengobatan tradisional masih menjadi primadona bagi masyarakat Indonesia, khususnya masyarakat yang ada di desa Semen, kecamatan Semen Utara, kabupaten Kediri. Namun, masyarakat selama ini masih membeli bahan-bahan obat tradisional di pasar. Padahal desa tersebut memiliki potensi untuk melakukan budidaya tanaman obat keluarga seperti tanaman jahe, sereh, kunyit, temulawak, dan kencur. Lahan pemukiman di desa Semen mencapai sekitar seperempat luas total lahan $(48,81 \mathrm{Ha})$ yang memberi peluang gerakan budidaya tanaman obat keluarga dapat dilakukan di halaman atau pekarangan rumah warga. Oleh karena itu, tim pengabdian berinisiatif membuat program Gerakan Budidaya Tanaman Obat Keluarga (TOGA) dengan tujuan untuk memberikan pengetahuan, pemahaman, dan keterampilan ke masyarakat desa terkait pemanfaatan tanaman obat, cara budidaya tanaman obat, dan cara mengolah tanaman obat untuk dikomsumsi. Adapun kegiatan yang dilakukan adalah mengajak warga setempat untuk bersama-sama membuat lahan di depan rumah masing-masing dan menanam beberapa jenis tanaman obat. Selanjutnya, warga setempat diberikan sosialisasi terkait manfaat dan praktik langsung cara mengolah tanaman obat tersebut. Alhasil, gerakan menanam obat keluarga ini mampu mengubah kesadaran, keterampilan, dan perilaku gaya hidup sehat masyarakat di desa Semen.
\end{abstract}

Kata Kunci: gerakan budidaya, tanama obat keluarga, desa sehat

Artikel diterima : 28 Maret $2020 \quad$ direvisi : 28 Juni 2020 disetujui : 28 Juli 2020 


\section{Pendahuluan}

Menikmati hidup dengan kondisi sehat jasmani dan mental adalah anugerah dari Sang Pencipta yang sudah selayaknya disyukuri. Mengingat kesehatan jasmani dimasa sekarang ini adalah hal yang berharga dan bernilai mahal secara materi dan non-materi. Tidak hanya pada sektor perekonomian melainkan juga sektor kesehatan menjadi salah satu tolak ukur kemakmuran suatu negara (Muljana, n.d.). Oleh karena itu, kerjasama antara pemerintah dan masyarakat dalam mewujudkan masyarakat yang sehat menjadi salah satu target nasional yang sangat dinanti pencapaiannya. Salah satu langkah konkritnya adalah mengkondisikan masyarakat untuk peduli dengan hal-hal yang terkait dengan perwujudan hidup sehat.

Meningkatkan kepedulian masyarakat terhadap kesehatan keluarga dapat mewujudkan masyarakat yang maju dan mandiri. Oleh karena itu melakukan sebuah gerakan untuk meningkatkan kesehatan keluarga harus dilakukan oleh seluruh stake holder (Purnama, 2019). Pada penelitian sebelumnya juga memaparkan bahwa partisipasi seluruh lapisan masyarakat dalam meningkatkan kesehatan lingkungan sangat dibutuhkan untuk menjadi modal awal dalam melakukan perubahan pola pikir pada masyarakat umum mengenai pentingnya kesehatan, khususnya kesehatan keluarga (Sitaro et al., 2017).

Membahas mengenai kesehatan masyarakat, khususnya kesehatan keluarga sangat erat kaitannya dengan bentuk dan proses pengobatan yang ada di tengah masyarakat. Sesungguhnya pengobatan di Indonesia terdiri dari dua jenis yaitu jenis pengobatan medis dan pengobatan tradisional. Pengobatan medis sering menggunakan obat Kimia yang dilakukan oleh tenaga berpendidikan medis formal dengan metode terstandarisasi nasional, sedangkan pengobatan tradisional masih minim standarisasi karena pengetahuan masyarakat awam yang terbatas (Utami, 2018).
Walaupun demikian, pengobatan tradisional masih menjadi primadona di kalangan masyarakat karena bahan yang digunakan mudah diperoleh di pasar, harga bahan terjangkau, pengolahan yang cukup sederhana, serta melakukan budidaya tanaman obat tradisional mudah dilakukan atau lazimnya disebut budidaya tanaman obat keluarga (TOGA) (Shanty, 2017). Bahkan beberapa penelitian sebelumnya telah membuktikan bahwasanya dengan menggerakkan masyarakat untuk melakukan budidaya tanaman obat dan mengetahui cara mengonsumsi tanaman tersebut maka cukup signifikan meningkatkan kepedulian dan kesadaran masyarakat untuk senantiasa menjaga kesehatan dengan memanfaatkan tanaman obat yang mudah ditemui dan dibudidaya (Dwisatyadini, n.d.; Sambara et al., 2016).

Meskipun budidaya tanaman obat keluarga mudah dilakukan, warga yang ada di desa Semen kabupaten Kediri masih kurang memiliki motivasi untuk melakukan budidaya tanaman obat padahal di desa tersebut telah terbentuk kelompok penggiat tanaman obat keluarga atau lazimnya disingkat TOGA. Bahkan sosialisasi telah dilakukan pemerintah namun peserta sosialisasi masih terbatas pada anggota kelompok penggerak TOGA, PKK, Puskesmas dan kelompok lain yang ada di desa Semen. Di samping itu, lahan pemukiman di desa Semen mencapai sekitar seperempat luas total lahan $(48,81 \mathrm{Ha})$ yang memberi peluang gerakan budidaya tanaman obat keluarga dapat dilakukan di halaman atau pekarangan rumah warga seperti tanaman jahe, sereh, kunyit, temulawak, lengkuas, dan kencur.

Budidaya TOGA di kalangan masyarakat desa bermanfaat untuk meningkatkan kesadaran masyarakat untuk senantiasa menjaga kesehatan, melakukan usaha pencegahan berbagai macam penyakit dengan rutin mengonsumsi TOGA yang aman setiap hari, dan dapat digunakan sebagai pengobatan berbagai penyakit. TOGA dapat diperoleh disekitar ling- 
kungan, diramu secara mandiri dan ditanam sendiri tanpa tenaga medis (Agil et al., 2019). Oleh sebab itu, pemanfaatan TOGA perlu digalakkan guna meningkatkan kesehatan masyarakat, kemandirian masyarakat, dan dapat menjadi nilai tambah ekonomi masyarakat jika dikelola dengan baik oleh kelompok TOGA yang ada di desa (Purnama, 2019).

Selain inisiatif dan motivasi warga yang masih rendah dalam melakukan budidaya, masih banyak juga warga di desa Semen yang belum memaksimalkan pemanfaatan TOGA sebagai salah satu terapi pengobatan keluarga. Minimnya fasilitas dan informasi bagi masyarakat terutama golongan masyarakat menengah ke bawah menyebabkan pemanfaatan toga masih kurang dirasakan (Nurjanah et al., 2019). Oleh karena itu, tim pengabdian ini akan melakukan sebuah kegiatan untuk mengatasi permasalahan-permasalahan yang telah dipaparkan sebelumnya yaitu kegiatan Gerakan Budidaya Tanaman Obat Keluarga sebagai Kepedulian Masyarakat Menuju Desa Sehat di desa Semen kabupaten Kediri.

Tujuan dari program tersebut adalah meningkatnya motivasi warga untuk membudidayakan tanaman obat, pemanfaatan tanaman TOGA untuk alternatif obat alami, serta para ibu-ibu di desa Semen mendapat bekal keterampilan mengolah salah satu jenis tanaman obat yaitu temulawak menjadi produk obat yang siap dikonsumsi oleh para anggota keluarga bahkan berpotensi menjadi produk obat yang dapat dipasarkan (Pujiharti, 2012).

\section{Pelaksanaan dan Metode}

Tim penyelenggara kegiatan Gerakan Budidaya TOGA ini bekerjasama dengan pihak Puskesmas dan Pembina Kesejahteraan Keluarga (PKK) di masingmasing RT-RW di desa Semen. Pelaksanaan kegiatan Gerakan Budidaya TOGA disajikan dalam empat bentuk kegiatan yaitu observasi dan wawancara, pembuatan taman TOGA, sosialisasi manfaat TOGA, dan pelatihan pengolahan TOGA (temulawak).

Dalam pelaksanaan Program ini, tim pengabdian menggunakan metode pendekatan Participatory Rural Appraisal (PRA) (Dai, 2018). Metode PRA yang melibatkan masyarakat mulai dari tahap perencanaan, pelaksanaan, pemanfaatan dan evaluasi (Zakaria, 2018). Pendekatan tersebut memungkinkan masyarakat desa saling membagi, menambah dan menganalisis pengetahuan tentang kondisi lingkungannya dalam rangka membuat perencanaan dan tindakan. Metode PRA merupakan cara yang digunakan dalam melakukan kajian untuk memahami keadaan atau kondisi desa dengan melibatkan partisipasi masyarakat, atau pengkajian/penilaian (keadaan) desa secara partisipatif (Mustanir et al., 2019).

Penggunaan teknik metode PRA memiliki kekhasan tersendiri. Dimana, metode ini menekankan pada prinsip partisipatif. Artinya, masyarakat dilibatkan secara penuh dan berarti dalam keseluruhan proses program Gerakan Budidaya Tanaman Obat Keluarga (TOGA). Adapun manfaat dari prinsip partisipatif ini adalah menyajikan program sesuai kebutuhan warga dan rasa kepemilikan warga masyarakat terhadap program ini menjadi lebih tinggi. Pengetahuan, pemahaman, dan keterampilan dapat diperoleh warga yang berpartisipasi aktif sehingga di masa akan datang, warga dapat melanjutkan dan melaksanakan program ini secara mandiri. Dengan demikian tujuan utama dari pelaksanaan kegiatan pengabdian ini dapat tercapai dan membawa manfaat kepada masyarakat setempat. 


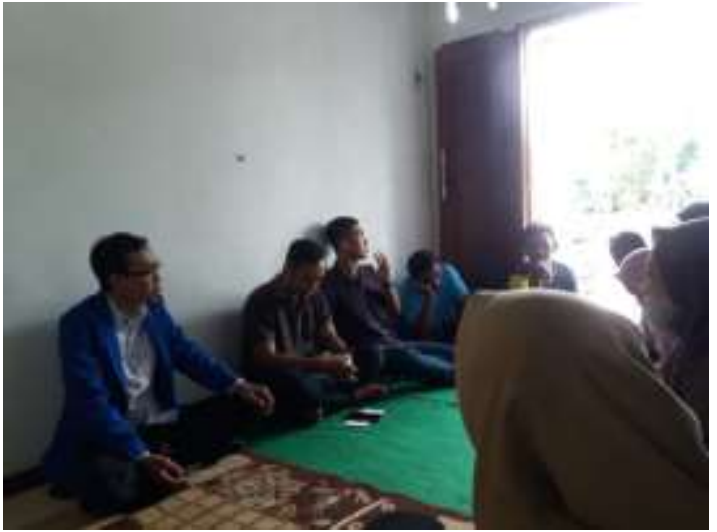

Gambar 1. Koordinasi dengan warga desa Semen

Langkah penerapan PRA dimulai dari koordinasi. Koordinasi dapat dilihat pada gambar 1. Koordinasi dilakukan dengan warga sekitar dan pihak kelompok dusun semen. Koordinasi membahas mengenai tahapan kegiatan pengabdian yang akan dilakukan selama waktu 1 bulan kedepan. Adapun kegiatan yang dilaksanakan selama masa pengabdian ini yaitu kegiatan pengambilan data awal melalui proses observasi dan wawancara, bekerjasama dengan tim PKK dalam kegiatan pembuatan taman tanaman obat keluarga (TOGA), dan kegiatan terakhir melakukan sosialisasi kepada masyarakat mengenai manfaat TOGA yang akan dibudidaya serta pelatihan cara mengolah dan mengonsumsi TOGA tersebut.

Pengumpulan data awal dilakukan dengan proses observasi dan wawancara selama 1 minggu. Kegiatan pertama adalah menjalin komunikasi dengan pihak pemerintah desa Semen serta warga desa Kemudian dilanjutkan dengan bersilaturahmi sekaligus melakukan dialog ke rumah penduduk dan Kepala dusun, ketua adat, tokoh-tokoh agama, pemuda sekaligus untuk mencari tahu permasalahan-permasalahan yang ada di desa Semen. Cara ini merupakan pendekatan secara persuasif, yang nantinya diharapkan bisa mengajak mayarakat untuk berpartisipasi dalam pelaksanaan realisasi dari program yang telah dirancang. Ketiga kegiatan selanjutnya juga tidak terlepas dari keterlibatan masyarakat desa agar target kegiatan dapat dicapai dan kegiatan pengabdian mampu memberikan manfaat dan dampak positif bagi kehidupan masyarakat desa.

\section{Hasil dan Pembahasan}

Setelah melakukan kegiatan Pengabdian kepada Masyarakat di dusun Semen, desa Semen maka dapat dilaporkan pencapaian yang telah berhasil dilaksanakan dalam beberapa bentuk kegiatan kerja. Berikut pemaparan hasil atau pencapaian target dalam kegiatan pengabdian masyarakat terkait budidaya dan pemanfaatan Tanaman Obat Keluarga (TOGA):

1. Observasi dan wawancara,

Kegiatan ini dilakukan selama 1 minggu termasuk lokakarya mini. Proses observasi ini dilakukan saat kunjungan ke rumah-rumah kepala dusun, bertanya dengan kepala desa, sekretaris desa, ketua RT, ibu PKK, tempat-tempat pendidikan, tempat ibadah, petugas kesehatan, dan juga masyarakat di dusun Semen Kegiatan ini dilakukan untuk menggali masalah yang ada di dusun Semen, baik masalah dari individu, kelompok dan sarana umum.

Dimulai dari tanggal 11 Februari 2020. Pada tanggal 20 Februari 2020 diadakan lokakarya desa. Adapun salah satu masalah yang terungkap pada pengumpulan data awal ini (observasi dan wawancara) adalah masalah kesehatan. Masyarakat masih me-nganggap bahwa biaya kesehatan cukup tinggi sehingga jika ada salah satu anggota keluarga yang sakit maka pihak keluarga harus siap dengan biaya pengobatan yang mahal. Oleh karena itu, pengabdian ini dilaksanakan untuk memberikan alternatif kepada masyarakat yang berkaitan dengan kesehatan. Jadi hasil yang dicapai pada kegiatan observasi dan wawancaara selama 1 minggu adalah dengan persentase mencapai $100 \%$.

\section{Pembuatan Taman Tanaman Obat Keluarga (TOGA)}

Kegiatan ini dilaksanakan sesuai rencana yang disepakati dengan pemerintah 
dan warga setempat. Kegiatan pembuatan taman TOGA ini dilaksanakan pada tanggal 20 Februari 2020 sampai tanggal 5 Maret 2020. Pada pelaksananaan penanaman TOGA yang pertama ini terkendala cuaca buruk sehingga proses penanaman sering tertunda. Modal pembuatan taman TOGA disediakan oleh tim, pemerintah desa, dan masyarakat desa setempat yang berupa berbagai macam tanaman TOGA. Taman TOGA tersebut dirawat oleh ibu-ibu PKK dusun Semen. Hasil capaian dari program kegiatan ini sesuai dengan target adalah $100 \%$.

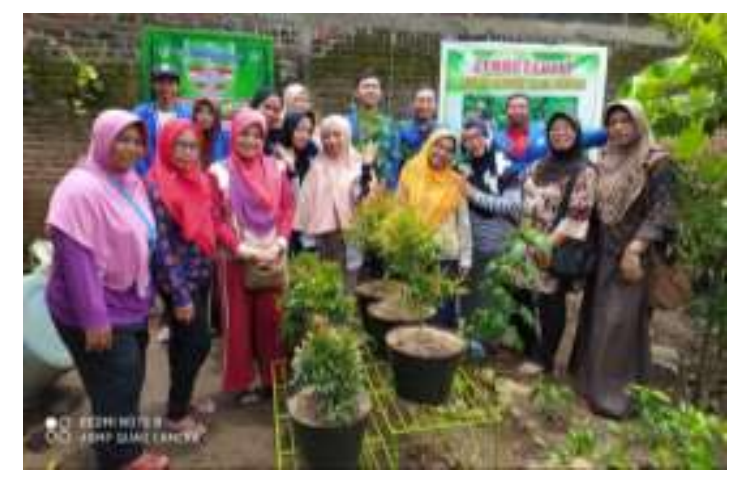

Gambar 2. Kerjasama membuat taman TOGA

Pembuatan Kebun TOGA melibatkan ibu-ibu PKK khususnya tim 3 yang telah terbentuk sebelum kegiatan ini dilaksanakan. Gambar 2 merupakan kegiatan yang menggambarkan kerjasama tim untuk menentukan tata layout kebun TOGA. Ibu-ibu PKK tim 3 merupakan Pengelola TOGA pada periode ini. Hasil yang didapatkan seperti pada gambar 3 . Taman TOGA dapat menjadi pembibitan untuk keperluan penanaman TOGA di Pekarangan warga. Hal ini juga didukung oleh kegiatan pengabdian sebelumnya yang menyimpulkan bahwa kegiatan yang bertujuan untuk menginisiasi keterlibatan ibu-ibu dalam memanfaatkan pekarangan rumah dengan TOGA mampu menyadarkan masyarakat bahwasanya TOGA sangat bermanfaat dan berguna bagi masyarakat di lingkungan perumahan, khususnya dalam menjaga kesehatan keluarga dan masyarakat luas (Aslamiah et al., 2017).

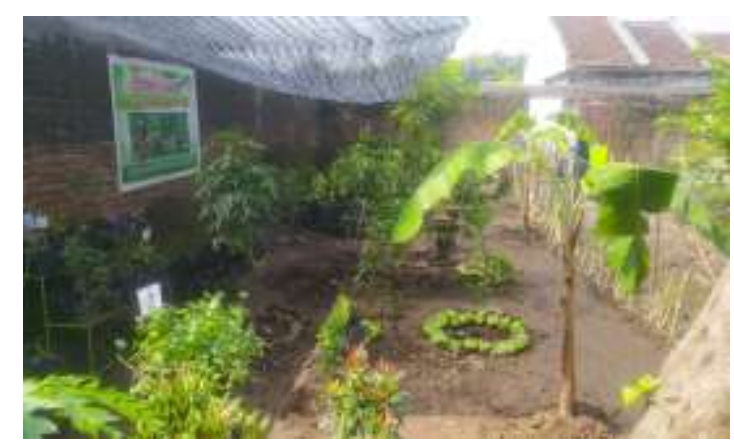

Gambar 3. Taman TOGA

Gambar 3 menggambarkan hasil pembuatan taman tanaman obat keluarga (TOGA) yang merupakan hasil kerjasama tim dalam menentukan dan menata taman. Terlihat taman telah ditanami beberapa jenis tanaman obat yang mudah tumbuh dan dirawat oleh masyarakat secara bersamasama. Adapun tanaman yang terdapat di taman tersebut meliputi jahe, sereh, kunyit, temulawak, dan kencur, serta tambahan beberapa tanaman atas inisiatif ibu-ibu PKK yaitu tanaman jeruk nipis, sirih, cabe, brotowali, belimbing dan belimbing wuluh. Tanaman obat ini diharapkan dapat dibudidayakan dalam jumlah banyak sehingga setiap keluarga/rumah mendapatkan bibit yang dapat dibudidayakan sendiri di halaman rumah masing-masing. Selama masa pembibitan, pihak yang akan membantu untuk merawat tanaman-tanaman obat tersebut adalah ibu-ibu PKK tim 3 dibantu oleh warga lainnya yang dengan sukarela ingin terlibat membantu merawat TOGA.

\section{Sosialisasi manfaat TOGA}

Kegiatan ini dilaksanakan sesuai rencana yang disepakati dengan pemerintah dan warga setempat. Salah satu tolak ukur keberhasilan kegiatan ini terletak pada terjalinnya kerjasama dan koordinasi yang berkesinambungan dengan semua pihak terkait (pemerintah setempat dan warga) dalam pelaksanaan sosialisasi manfaat TOGA (Susanto, 2017). Di samping itu, efektifitas pemberian sosialisasi tentang tanaman obat merupakan langkah yang tepat untuk meningkatkan pengetahuan dan pemahaman masyarakat mengenai tanaman 
obat keluarga (Choironi et al., 2019; Yulianto, 2016).

Adapun narasumber dari kegiatan sosialisasi ini adalah tim medis dari Puskesmas setempat. Secara rinci pemateri menjelaskan mengenai pentingnya hidup sehat dan manfaat olahan jamu sederhana dengan menggunakan tanaman obat keluarga yang telah ditanam di halaman rumah masing-masing. Adapun materi sosialisasi yang disampaikan narasumber meliputi ragam tanaman obat, fungsi masing-masing tanama obat, cara menanam dan merawat, dan cara sederhana yang dapat ditempuh untuk memanfaatkan tanaman obat untuk menjaga kesehatan keluarga.

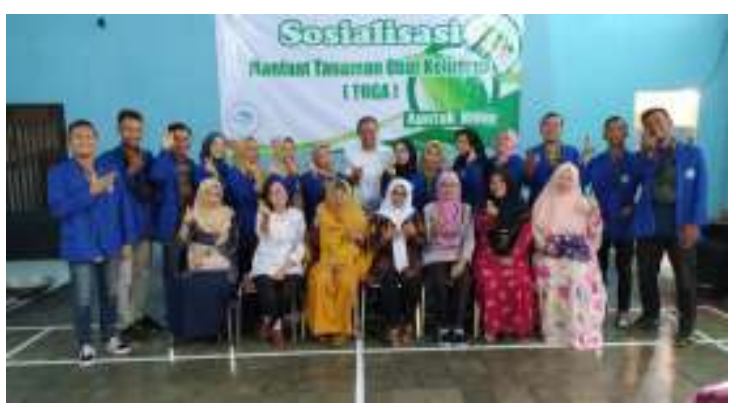

Gambar 4. Kegiatan Sosialisasi Manfaat TOGA

Bukti Kegiatan pada gambar 4. Kegiatan sosialiasi melibatkan dua dusun desa semen yaitu dusun Bajang dan dusun Semen. Kegiatan meliputi sosialisasi manfaat TOGA dan pengolahan produk TOGA. Berdasarkan survei yang bertujuan menggali pemahaman peserta sosialisasi, diperoleh kesimpulan bahwa sosialisasi yang dilakukan oleh tim pengabdian mampu memberikan pengetahuan dan pemahaman kepada ibu-ibu mengenai manfaat tanaman obat dan pentingnya kegiatan budidaya TOGA di halaman rumah masing-masing untuk mencegah dan memelihara anggota keluarga dari gangguan kesehatan.

Kegiatan sosialisasi TOGA ini juga telah dilakukan pada pengabdian sebelumnya dan telah terbukti mampu meningkatkan pemahaman peserta mengenai ragam tanaman obat, cara melakukan budidaya tanaman obat, cara sederhana mengo- lah tanaman obat, dan fungsi tanaman obat serta menyadarkan warga bahwa dengan memanfaatkan tanaman obat yang ada disekitar rumah merupakan pertolongan pertama bagi keluarga yang sakit sebelum berobat ke fasilitas kesehatan (Choironi et al., 2019; Sari et al., 2015; Taryono et al., 2017). Pada pengabdian ini, tim sangat berupaya membangun dan mempertahankan semangat para warga khususnya ibu-ibu PKK dalam melakukan budidaya TOGA.

\section{Pelatihan Pengolahan Temulawak}

Kegiatan ini dilaksanakan sesuai rencana yang disepakati dengan pemerintah dan warga setempat. Temulawak disediakan dari tim pengabdian. Adapun trainer yang memandu proses pelatihan berasal dari dosen Biologi dan Sistem Informasi Universitas Nusantara PGRI Kediri. Proses pembuatan serbuk obat temulawak dipraktekkan langsung di depan warga dan beberapa warga secara sukarela ikut terlibat langsung (Sucipto et al., 2019). Bahan yang dibutuhkan adalah temulawak, gula pasir, kayu manis, dan daun serai. Proses pembuatan dimulai dari pembersihan temulawak, kemudian temulawak tersebut digiling dan diperas untuk diambil sarinya. Selanjutnya sari dari temulawak tersebut didiamkan agar mengendap. Sari bening dari temulawak kemudian dimasak bersama dengan gula pasir, kayu manis, dan daun serai sampai menjadi kering seperti bubuk. Proses pembuatannya sekilas tergambarkan pada gambar 5.

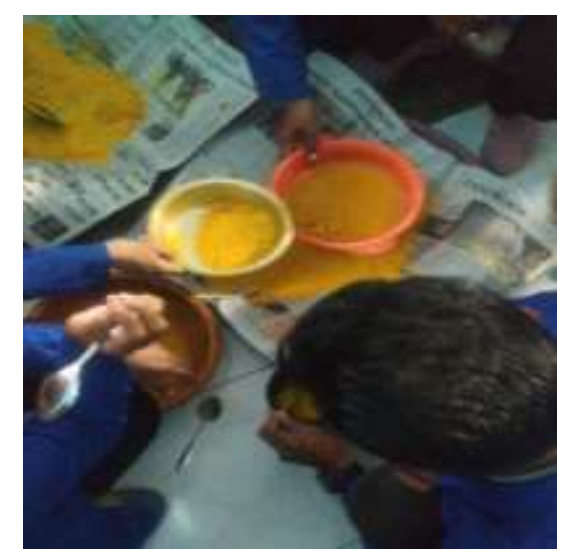

Gambar 5. Proses Pembuatan Produk 
Kemudian bubuk temulawak tersebut disaring diambil bubuk yang lemut dan yang kasar ditumbuk lagi hingga lembut. Setelah itu bubuk tersebut dimasukan kedalam kemasan. Produk serbuk temulawak ini pun diberi nama "NGELAWAK" (Ngecam Temulawak). Tampilan produk sepeti pada gambar 6. Hasil yang dicapai pada kegiatan ini adalah $80 \%$.

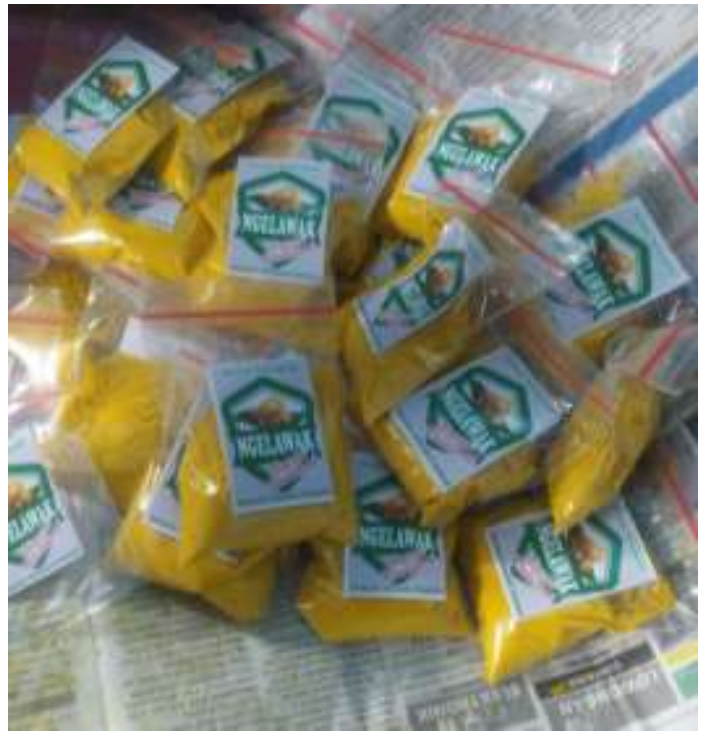

Gambar 6. Produk Pelatihan

"NGELAWAK" (Ngecam Temulawak)

Hasil kegiatan ini juga sesuai dengan kegiatan pengabdian yang telah dilakukan sebelumnya yang menyimpulkan bahwa kegiatan pelatihan pengolahan TOGA mampu meningkatkan pengetahuan dan keterampilan warga dalam memanfaatkan TOGA yang dibudidaya serta mampu meningkatkan kesadaran diri warga untuk berpartisipasi melakukan budidaya TOGA di halaman rumah masing-masing (Harfiani et al., 2019).

Terdapat 4 kegiatan dalam program pengabdian ini yang telah dilakukan yaitu pengambilan data awal melalui proses observasi dan wawancara, pembuatan taman TOGA, Sosialisasi manfaat TOGA, dan pelatihan olahan TOGA. Capaian pelaksanaan kegiatan tersebut tidak terlepas dari faktor yang mendukung keberhasilan pelaksanaan program ini yaitu respon antusias dari warga setempat dan perangkat desa, tersedianya bantuan informasi dari pemerintah desa dan Puskesmas, dan terdapat salah satu warga di RT 0/RW 01 yang bersedia memberikan fasilitas tempat untuk pembuatan Taman TOGA sebagai taman percontohan untuk warga yang lain serta tempat pembibitan TOGA sehingga para warga mudah memperoleh bibit untuk taman TOGA di halaman rumah masingmasing.

Secara keseluruhan, kegiatan-kegiatan dalam pelaksanaan pengabdian kepada masyarakat ini terlaksana sesuai tujuan dan target-target yang diharapkan. Buktinya, masyarakat telah memperoleh pengetahuan, pengalaman, dan keterampilan mengenai budidaya dan pemanfaatan tanaman obat rumah tangga. Bukti-bukti tersebut menjadi modal utama meningkatnya kepedulian masyarakat terhadap kesehatan keluarga.

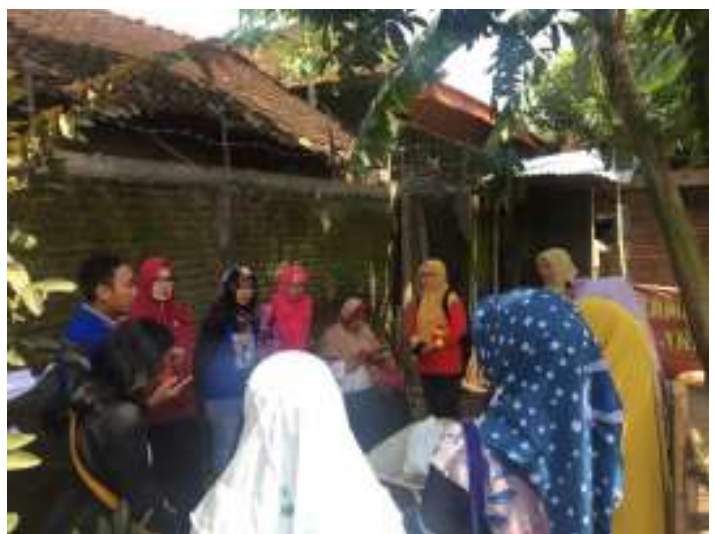

Gambar 7. Dukungan koordinasi dengan masyarakat setempat

Dukungan terkait kelanjutan taman TOGA ditunjukkan pada gambar 7 . Dukungan dari masyarakat desa ini dapat mendukung taman TOGA menjadi lestari dan menjadikan gerakan hidup sehat sebagai gaya hidup masyarakat.

Selain faktor pendukung, terdapat pula faktor penghambat yang dialami dalam menjalankan program yaitu diawal kegiatan, beberapa warga masih menganggap budidaya TOGA belum penting sehingga tim memerlukan bantuan para perangkat desa untuk menggerakkan warga terlibat pada kegiatan-kegiatan dalam pengabdian ini. Melalui peran serta 
perangkat desa, mampu mempengaruhi warga dan cukup banyak yang tertarik pada Program ini. Oleh karena itu, perlu dilakukan usaha yang berkesinambungan supaya program budidaya dan pemanfaatan TOGA menjadi program favorit bagi masyarakat desa Semen dan kegiatan pengabdian ini dapat dilanjutkan oleh masyarakat.

\section{Penutup}

\section{Simpulan}

Kegiatan pengabdian kepada masyarakat ini yang meliputi empat kegiatan yaitu observasi dan wawancara, pembuatan taman TOGA, sosialisasi manfaat TOGA, dan pelatihan pengolahan TOGA (temulawak). Semua kegiatan berjalan dengan lancar berkat dukungan perangkat desa dan warga masyarakat. Pembuatan taman TOGA telah menumbuhkan semangat ibu-ibu PKK untuk melakukan budidaya beberapa tanaman obat seperti jahe, sereh, kunir, temulawak, kencur dan beberapa tambahan tanaman atas usulan ibu-ibu PKK yaitu tanaman jeruk nipis, sirih, cabe, brotowali, belimbing dan belimbing wuluh.

Semangat para warga semakin meningkat untuk memanfaatkan TOGA setelah beberapa warga mengikuti sosialisasi manfaat TOGA yang disampaikan oleh narasumber dari bidang kesehatan. Tidak hanya mendapat semangat, pengetahuan, dan pemahaman mengenai TOGA, masyarakat juga diberikan kesempatan untuk belajar mengolah salah satu macam TOGA yaitu temulawak melalui pelatihan pengolahan TOGA (temulawak).

Berdasarkan hasil wawancara dan survei yang dilakukan tim diperoleh kesimpulan bahwa masyarakat merasakan dampak positif dari kegiatan-kegiatan pengabdian masyarakat ini. Masyarakat desa Semen kabupaten Kediri paham dan menyadari manfaat keberadaan TOGA untuk kesehatan keluarga dan memiliki inisiatif untuk melakukan budidaya TOGA.

\section{Saran}

Masyarakat diharapkan mengelola taman TOGA secara berkesinambungan dan stake holder terus melakukan kerjasama dan koordinasi agar gerakan budidaya tanaman obat terus dilakukan oleh masyarakat di desa Semen demi mewujudkan masyarakat yang sehat. Selain itu, stake holder juga diharapkan terus melakukan pengembangan produk-produk TOGA yang dapat dipasarkan dan menjadikan produk olahan temulawak "Ngelawak" sebagai industri UMKM di desa Semen sebagai upaya peningkatan kemandirian dan kesejahteraan warga. Selain itu, pengolahan TOGA yang lainnya seperti kunyit, jahe, kencur, sereh, jeruk nipis, sirih, cabe, brotowali, belimbing dan belimbing wuluh juga dapat coba sehingga menjadi produk obat herbal yang dapat dikomsumsi masyarakat luas. Kegiatan ini diharapkan semakin mendukung upaya masyarakat untuk menjaga ketahanan keluarga dari aspek kesehatan.

\section{Daftar Pustaka}

Agil, M., Wahyuni, T. S., Studiawan, H., \& Rakhmawati, R. (2019). Optimalisasi Pemanfaatan Herbal Untuk Kesehatan Masyarakat Desa Wajik Kabupaten Lamongan Provinsi Jawa Timur. Jurnal Pengabdian Kepada Masyarakat, 24(4), 883.

https://doi.org/10.24114/jpkm.v24i4.125 15

Aslamiah, S., Afitah, I., Mariaty, D., Peningkatan, :, Masyarakat, K., Perberdayaan, M., Dalam«, W., Program, M., Kehutanan, S., Kehutanan, F., Universitas, P., Palangkaraya, M., Rta, J., Km, M., Raya, P., \& Tengah, K. (2017). Peningkatan Kesehatan Masyarakat melalui Pemberdayaan Wanita dalam Pemanfaatan Lahan Pekarangan dengan Tanaman Obat Keluarga (TOGA) (The Increasing Of Community Health Through Empowerment Thewomen In The Utilization Of The Yard With Family Medicine Plants. Pengabdianmu, 2(2), 111-117. http://jurnal.umpalangkaraya.ac.id/ejurna 
$1 /$ pgbmu

Choironi, N. A., Wulandari, M., \& Susilowati, S. S. (2019). Pengaruh edukasi terhadap pemanfaatan dan peningkatan produktivitas tanaman obat keluarga (TOGA) sebagai minuman herbal instan di Desa Ketenger Baturraden. Kartika : Jurnal Ilmiah Farmasi, 6(1), 1. https://doi.org/10.26874/kjif.v6i1.115

Dai, W. (2018). Improvement and Implementation of Feature Weighting Algorithm TF-IDF in Text Classification. 2018 International Conference on Network, Communication, Computer Engineering (NCCE 2018).

Dwisatyadini, M. (n.d.). Optimalisasi Peran Sains dan Teknologi untuk Mewujudkan Smart City 237. Retrieved June 25, 2020, from http://repository.ut.ac.id/7079/1/UTFMIP A2017-10-mutimanda.pdf

Harfiani, E., Anisah, A., \& Irmarahayu, A. (2019). Pemberdayaan masyarakat dengan pelatihan pembuatan minuman kesehatan dari Tanaman Obat Keluarga (TOGA). Riau Journal of Empowerment, 2, 37-42. https://doi.org/10.31258/raje.2.2.37-42 Muljana, V. S. (n.d.). Tolak ukur keberhasilan dan kemampuan pelayanan kesehatan suatu - PDF Free Download. Retrieved June 25, 2020, from https://adoc.tips/babi-pendahuluan-tolak-ukur-keberhasilandan-kemampuan-pela.html

Mustanir, A., Hamid, H., \& Syarifuddin, R. N. (2019).

PEMBERDAYAAN KELOMPOK MASYARAKAT DESA DALAM PERENCANAAN METODE PARTISIPATIF. Moderat: Jurnal Ilmiah Ilmu Pemerintahan, 5(3), 227-239. https://doi.org/10.25147/MODERAT.V 5I3.2677

Nurjanah, S. R., Nurazizah, N. N., Septiana, F., \& Shalikhah, N. D. (2019). Peningkatan Kesehatan Masyarakat Melalui Pemberdayaan Wanita dalam Pemanfaatan Pekarangan dengan Tanaman Obat Keluarga (TOGA) di Dusun Semawung. Community Empowerment, 4(1), 20-25.

Pujiharti, Y. (2012). Budidaya Tanaman Obat Keluarga (Toga). Lampung: Balai Pengkajian Teknologi Pertanian.

Sambara, J., Nyoman Yuliani, N., \& Yuniati Emerensiana, M. (2016).
PEMANFAATAN TANAMAN OBAT

TRADISIONAL OLEH

MASYARAKAT KELURAHAN

MERDEKA KECAMATAN KUPANG

TIMUR 2016. Jurnal Info Kesehatan,

4(1), 1113-1124.

https://media.neliti.com/media/publicatio ns/259693-utilization-of-traditional-drugplant-by-2fb67fc7.pdf

Sari, I., Yuniar, Y., Siahaan, S., Riswati, R., \& Syaripuddin, M. (2015). Tradisi

Masyarakat dalam Penanaman dan Pemanfaatan Tumbuhan Obat Lekat di Pekarangan. Jurnal Kefarmasian Indonesia, 5.

https://doi.org/10.22435/jki.v5i2.4407.12 3-132

Shanty, W. Y. (2017). SEMULA (Sirup

Temulawak) Olahan Toga untuk

Pemberdayaan Masyarakat Desa

Kepuharjo, Karangploso Kabupaten

Malang. Jurnal Pengabdian Masyarakat Universitas Merdeka Malang, 1(1).

Sitaro, S. K., Gosal, R., \& Singkoh, F. (2017). Partisipasi Masyarakat Dalam

Meningkatkan Kesehatan Lingkungan Di Desa Kisihang Kecamatan Tagulandang Selatan Kabupaten Sitaro. Jurnal Eksekutif, 1(1).

Sucipto, S., Andriyanto, T., Nadliroh, K., Indrajaya, D., Mustofa, M. A., \& others. (2019). PELATIHAN PENGEMASAN DAN PENYULUHAN PEMBUATAN PUPUK KOMPOS: DESA

PUSHARANG. Jurnal Terapan Abdimas, 4(1), 13-16.

Susanto, A. (2017). (PDF) Komunikasi Dalam Sosialisasi Tanaman Obat Keluarga (Toga) Di Kecamatan Margadana. Jurnal Para Pemikir, 6(2), 111-117.

https://www.researchgate.net/publication 1329265370_Komunikasi_Dalam_Sosiali sasi_Tanaman_Obat_Keluarga_Toga_Di _Kecamatan_Margadana

Taryono, N., Taryono, N., \& Emmyzar, N. (2017). Pentingnya Peranan Toga. Pentingnya Peranan Toga, 1(2), 117125.

https://doi.org/10.21082/bullittro.v1n2.19 86.117-125

Utami, E. R. (2018). Hubungan Pengetahuan Keluarga Dengan Penggunaan Obat Tradisional Di Desa Nunggalrejo Kecamatan Punggur Kabupaten Lampung Tengah. 
Yulianto, S. (2016). Pengetahuan Masyarakat

Tentang Taman Obat Keluarga Di

Nglinggi, Klaten Selatan. Jurnal

Kebidanan Dan Kesehatan Tradisional, 1(2), 119-123.

https://doi.org/10.37341/jkkt.v1i2.79

Zakaria, Z. (2018). Modifikasi Konsep Participatory Rural Apraisal untuk Pembekalan Kuliah Kerja Nyata Mahasiswa di Jawa Barat, Indonesia. Dharmakarya, 7(1), 38-45. https://doi.org/10.24198/dharmakarya. v7i1.14592 